\title{
Farewell Ritual and Transmigrating Souls: Secondary Funeral of the Atțappādi Kựumbas
}

\author{
Manjula Poyil \\ Department of History and Heritage Studies, University of Kannur, Kerala, India \\ E-mail: poyilmanjula@yahoo.com
}

KEYWORDS Death Ceremony. Funeral Car. Communion of the Soul. Ossuary

\begin{abstract}
This article examines the ritual importance of the secondary funeral of the Kurumbas and places it in the context of tribal religion and social relations. Among a chain of ceremonies that mark a tribal funeral, secondary funeral is the most elaborate and ritually the most complex. Tribal people all over the world practice secondary funerals but in Kerala only two tribes, namely, Kurumbas and the Mudugas of Attappadi, practice it. As the most primitive tribal groups now living in Kerala, the cultural practices of these tribes are exceptionally relevant to the study of archaic societies. The ritual is an elaborate process and is the formal ceremony by which the souls of the dead of a fixed period are cheerfully sent to the world of the spirits with the accompaniment of song, music and blood sacrifice. It also involves the retrieval and reburial of the relics of the dead. Spirit worship and ancestor worship are the basic elements of the religion of the Attappādi tribes. Rituals like secondary funeral have diametrically opposite roles in a tribal society - while helping to maintain tribal unity and solidarity, it exhaust the surplus necessary for an economic growth. However, the advancing process of acculturation is bringing about a crisis in religious practices based on ancestor-cult and is a pointer to the slow but steady transformation.
\end{abstract}

\section{INTRODUCTION}

Most of the tribes in India practice secondary burial, but among the 36 different tribal communities inhabiting the south western Indian state of Kerala, only two - the Kurumbas and Mudugas of Attappādi - perform it, and is commonly known among them as Cîru. Funeral ceremonies are the most elaborate among the sacred functions of the tribal communities of Kerala, as elsewhere, and in spite of great amount of urbanization and acculturation brought about by non-tribal migration to the tribal areas, most of the tribes still persist on maintaining their death customs intact. Secondary funerals assume importance in the context of the extremely archaic nature of the ritual process involving ancestorcult and animal sacrifice. Though there are numerous studies on the life and culture of the Kurumbas (Thurston 1909; Luiz 1962; Mathur 1977; Sreekumar 1992; Tharakan 2003), none of them analyzes the ritual importance of funeral customs as a signifier of tribal culture and religion. A recent study (Poyil 2006) has revealed that for the Kurumbas, funeral customs are the principal form of ritual observance and ancestors are the central figures in their religious pantheon. The rituals associated with Cîru are the most sacred of all funeral customs which ultimately aim at making the spirits of the dead good and benevolent ancestors.

\section{SECONDARY FUNERAL}

Secondary funeral is the final death ceremony in which the bones/ ashes of a dead person, collected after burial or cremation, are ceremonially put into tribal or clan ossuaries, month/s or year/s later. It is a universal tribal practice and tribal communities all over the world have their own or common ossuaries for the purpose. According to tribal belief, only after performing this rite can the soul of the dead person acquire lasting peace and only then can death pollution come to an end.

One of the earliest and most original studies on funeral rites was that of Hertz in which he deals with the custom of secondary burial of the people of the Indonesian island of Borneo. Hertz (1960: 45-83) develops the central notion of his ideas regarding secondary burial thus: "there exists a kind of symmetry or parallelism between the condition of the body, which has to wait for a certain time before it can enter its final tomb, and the condition of the soul which will be properly admitted into the land of the dead only when the last funeral rites are accomplished... A very important part of the custom of secondary funeral therefore becomes the separation of the flesh from the bones. Two notions are linked to the bone-flesh dichotomy: 1) death is not completed in one instantaneous act, but is a lasting procedure which in many cases is only 
considered terminated when the dissolution of the body has ended; 2) death is not mere destruction but a transition: as it progresses, so does rebirth; while the old body falls to ruins, a new body takes shape with which the soul provided the necessary rites have been performed - will enter another existence...In other words, as the body decomposes, the soul is released. Now that the body is similar to that of the ancestors - bones free of death pollution - there is no longer any obstacle to the souls entering to the community". Gennep in his study (1960: 146) divided the rites of passages of birth and death into rites of separation or pre-liminal rites, rites of transition or liminal rites, and rites of incorporation or post-liminal rites. According to Gennep, "on first considering funeral ceremonies, one expects rites of separation to be their most prominent component, in contrast to rites of transition and rites of incorporation, which should be only slightly elaborated. A study of the data, however, reveals that the rites of separation are few in number and very simple, while the transition rites have a duration and complexity sometimes so great that they must be granted a sort of autonomy".

By examining the sepulchral and mortuary ritual that has survived from pre-historic times in the background of anthropological study of the cult of the dead among living aboriginals, James (1957: 122) maintained that "...the main purpose of the mortuary ritual is by no means confined to rendering the deceased harmless to the survivors. When this is the motive it is accomplished by making him at peace with himself and in harmony with his new surroundings in the spirit world; and also by removing from those who have come into intimate contact with the corpse and the mystery of death the dangerous sacred contagious they have contracted". Seligman (1964: 128) observed secondary funeral as a part of the regular mode of disposal, or due to the necessity of awaiting the correct funeral season or to the restlessness of the spirit. Similarly, Hartland (1964: 442) opined that among a very large number of peoples who practice earth-burial in one form or another, the ceremonies are not completed until the bones have been taken up, cleaned, and put into a place of final deposit. In many of the cases of subaerial deposit, also, the bones are collected at the end of a certain period and put into the tribal or local ossuary. Until this rite has been performed, the dead man is not at rest, and the mourning is not at an end.

Miles (1965: 170) in his extensive study on the social and economic aspects of secondary burial stated that "variations in the forms of secondary burial rites reflect differences in the ability with which the outlay necessary for their performance can be made by those incurring responsibilities for their sponsorships". Turner (1967: 97) maintained that without the secondary burial "the corpse can no longer be classified as living but cannot yet be classified as dead as the final ceremonies which will transform it into an ancestor have not been performed". Huntington and Metcalf (1979: 13-14) explained secondary burial as "distinct from the first burial or disposal taking place shortly after death - during which the remains of the deceased are recovered, ritually processed and moved to a new location". Block (1971) in his study of the secondary burial of the Merina of Madagascar noticed two kinds of funerary rites among them - an individual funeral which takes place soon after the death and a secondary funeral known as famadihana i.e., placing the corpse in ancestral tombs which occurs two years after the first funeral. Studying the secondary funeral of the double burial practicing Cantonese villagers of Africa, Watson (1982) observed that at first they buried the corpse in a coffin and left for approximately seven years. Then they collected bones and stored them in a ceramic urn until reburial in a tomb is possible. Sometimes reburial does not happen until decades or generations after death.

Meighan's study (1952: 149) of the mortuary customs among southern Indian tribes revealed that the Nilgiri Hills are the only spot where the traits of secondary burial are found in southern India and the relics of a first cremation are saved and cremated at a later date. Mandelbaum in his well-known article (1958) made a comparative analysis of secondary funeral of the Kotas, a tribe of the Nilgiri hills, and two American Indian tribes known as Cocopa and the Hopi. In the case of the Kota they observed two funeral ceremonies; the first being the "Green Funeral" in which the corpse is cremated shortly after the death of the person. The second, called "Dry Funeral", is held once a year (or once in two years) for all the deaths that have occurred since the last Dry Funeral was celebrated. The terms are an analogy to a cut plant. At the first funeral, the loss is green and fresh in the mind; at the 
second it is dried out, sere. Among the Cocopa, death ceremonies are the major events of tribal life; among the Hopi, they are brief and hurried affairs. The Cocopas conducted secondary funeral with very elaborate ceremony like the Kotas.

There have been very interesting studies on the funeral practices of the Todas of the Nilgiris (Rivers 1986; Walker 1986), who practice elaborate secondary funeral. The funeral ceremonies of a Toda may be prolonged to extend over a period of many months. Soon after the death the body is burnt and the general name of the ceremony on this occasion is etvainolkedr, the first day funeral. After an interval, which may vary greatly in length, a second ceremony is performed connected with certain relics of the deceased which have been preserved from the first occasion. The Toda name for the second funeral ceremony is marvainolkedr, the second day funeral. In a recent study, Debora Sutton (2002) depicted the 'savage' and 'tribal' character of the secondary funeral of the Todas and described the details of the ritual from the vantage point of the cruelty involved in the killing of innumerable buffaloes. Sutton traces out the decisive role the colonial laws played in putting this heinous custom to an end. It was the colonial intervention that forced the Todas to limit the sacrifice of animals to a nominal and token number of two or three and that too by avoiding their lingering death.

\section{Ancestor Worship and Primitive Religion}

Analyzing the cultural features of secondary burials, early writers found in the performances, the source of all religions. In the tribal context, ancestor-worship is still a universal form of religious expression. All primitive people believe in the immortality of human soul; all virtues and failures of their lives are attributed to the intervention of the spirits of their ancestors. Tribal religion may hence be described as animism or spirit-worship, of both malevolent and benevolent. During the 19th century anthropological theorists Edward Burnett Taylor and Herbert Spencer deemed ancestor worship to be the first inchoate religion. They assumed that primitive people were unable to comprehend the unseen. Taylor (1871: ii:113) remarked: "The worship of the Manes, or ancestors, is one of the great branches of the religion of mankind. Its principles are not difficult to understand, for they plainly keep up the social relations of the living world. The dead ancestors now passed into a deity, simply goes on protecting his own family and receiving suit and service from them as of old; the dead chief still watches over his own tribe, still holds his authority by helping friends and harming enemies, still rewards the right and sharply punishes the wrong".

A somewhat similar, but more elaborate, idea of ancestor-worship is outlined by Herbert Spencer. He (1896: i:411) writes: “'Anything', which transcends the ordinary, a savage thinks of as supernatural or divine: the remarkable man among the rest. The remarkable man may be simply the remotest ancestor remembered as the founder of the tribe; he may be a chief famed for strength and bravery; he may be a medicine-man of great repute; and then, instead of being a member of the tribe, he may be a superior stranger bringing arts and knowledge; or he may be one of a superior race gaining predominance by conquest. Being at first one or other of those, regarded with awe during his life, he is regarded with increased awe after his death; and the propitiation of his ghost, becoming greater than the propitiation of ghosts which are less feared, develops into an established worship. There is no exception then. Using the phrase ancestorworship in its broadest sense as comprehending all worship of the dead, be they of the same blood or not, we conclude that ancestor-worship is the root of every religion".

Although the opinions of Spencer and Taylor on the origin of religion are questioned by later anthropologists, as also by sociologists and archaeologists, they are not without relevance. Tribal cult of ancestor-worship has pervaded from generation to generation, from tribe to tribe and from place to place only with slight modifications caused by the process of acculturation. The basic features of ancestorworship, as pointed out by Taylor and Spencer, among all tribes, have been the same and tribes even today are found to follow some aspects of animism.

\section{THE KURUMBAS OF AṬṬPPĀDI}

Atțappâdi is situated in the Pâlakkâd district of Kerala, South India, which lies at a high elevation on the eastern slopes of the Western Ghâts, bounded on the north-east by the Nîlgiris 
and on the east by the Coimbatore districts of Tamilnadu. This area is noted for the three distinctive tribes- the Irulas, Mudugas and the Kurumbas- who share very little cultural traits common to other tribes of Kerala. Among the three, the $\mathrm{Ku}^{\circ}$ umbas and the Mudugas follow the same social system and religious practices, though the former are more primitive in terms of subsistence patterns and cultural practices. Proximity to the Tamil areas and cultural links with the three Tamil tribes of the Tôdas, Kôtas and the Badagas have had its strong influence on the language, lifestyle, religious practices and funeral ceremonies of the Atțappâdi tribes. The Kurumbas are also found in the Nîlgiris and the Coimbatore regions.

In Attappâdi, there are 16 Kurumba hamlets, all of which are situated in dense forests adjoining the Silent Valley. Hence, the people are largely shifting cultivators and food gatherers. Of all the settlements, the Todikki hamlet has a ritual prominence over others in ceremonies associated with the Cîru. Each Kurumba settlement (üru) has a tribal council consisting of a headman or Mûppan, a Vandâri, a Kurutalai, a Maṇnûkkâran and a Jâthikkâran. All the offices are hereditary. The Mûppan is the chief officiator in all tribal affairs of a settlement and is the foremost funeral functionary. The Mannûkkâran, the 'Knower of the Soil', supervises agricultural activities and acts as a specialist in funeral functions. The presence of the council is compulsory at the time of every funeral as well as at the Cîru. During the funeral, the Mannûkkâran fixes the spot of the grave and at the Cîru he leads the ritual performances.

\section{Pacca-câvu}

Before the secondary burial, the Kurumbas/ Mudugas performed an urgent ritual, called Pacca-câvu, to placate the spirits of those who succumbed to uncommon deaths (like those who commit suicide or are killed by wild animals, etc). Owing to the nature of their death, in accordance with the tribal custom, their bodies were not disposed of with the usual kind of ritual dances or songs; nor were their corpses ceremonially exposed on decorated funeral cars. Those who died during the monsoon also suffered the same fate because the inclement weather prevented elaborate outdoor rituals. The spirits of such persons turned out to be dreadful and hence their powers had to be reduced as far as possible before the completion of the final ceremony.

For Pacca-câvu they erect the same type of funeral car as they erect during the time of the secondary burial. The figure of the departed is made of a wild grass called tharuva-pullu and placed on a chair inside the funeral car. The female mourners and kinswomen sit around the chair wailing and invitees and other members of the settlement dance around the car day and night for three days. All those who are invited are given feasts on these days. On the afternoon of the third day the grass figure is taken out of the chair and burnt in the graveyard. After that, Nikal$n \hat{\imath}$ r-kuthu is performed.

\section{Nikal-nîr-kuthu}

This is a unique custom practiced by the Kurumbas/Mudugas for the merging of the soul (Nikal) of the deceased with the ancestor-souls. Normally it is performed just after the funeral but in the case of an uncommon death or in any other case where adverse circumstances prevent them from performing the usual funeral dance and music, it is carried out during the Pacca-câvu. The Nikal-nîr-kuthu is performed at the spot where the funeral car was placed before burial. While returning from the graveyard after the completion of the funeral, the son of the deceased person collects some leaves of the tharuva-pullu. The leaves collected should contain green as well as withered blades of grass. The green blade of grass signifies the soul of the newly deceased person whereas the withered ones stand for the ancestor-souls. The womenfolk place a padi (measuring jar) full of water.

The rite commences with the dropping of a piece of green grass into the water in the padi. Then a piece of withered grass is dropped into the jar after solemnly invoking the name of the senior-most ancestor in the family of the deceased say, his father. This process of throwing withered grass in the jar of water invoking the name of an ancestor (say mother, maternal and paternal uncles, brothers, sisters, etc) continues till the invocation of the name of the last member of the family who predeceased the newly departed person has been completed. If the withered piece of grass dropped into the jar of water immediately joins with the green grass already inside it, it is presumed that the particular ancestor-soul, whose name has been invoked, 
has warmly received the newly deceased person's soul. It means that the dead person is the beloved relative of that ancestor. If the two pieces of grass remain separate, the process is continued till the merging of the two pieces take place. All the kin-relatives of the deceased are bound to participate in this rite.

The rite is a simple method to find out which one of the ancestral souls readily accepts the guardianship of the newly deceased person's soul. Nikal-nîr-kuthu is indicative of the spiritual communion of the soul of the newly dead with the souls of his/her relatives who predeceased him/her. It does not lead to permanent salvation which can be obtained only with the completion of the Cîru. Those who face uncommon death will have no Nikal-nîr-kuthu performed on the day of the burial. In such cases it will be done on the day of Pacca-câvu. The two tribes also use oil (gingelly oil in the past and coconut oil nowa-days) at times when tharuvapullu is not available. While using oil, the two drops, one indicating the dead and the other an ancestor should merge together just like the grass pieces.

\section{The Ciru}

According to Kurumba tradition, the concluding post-burial ceremony of Cîru is to be conducted on the occurrence of every 101 deaths in a settlement. Hence the time-span between two Cîrus will be more or less to 10 or 20 years. This traditional norm is no longer respected and a time lag of 20 or 30 years between two Cîrus is a common occurrence now, because of the huge expenditure entailed in celebrating it. The Cîru of a settlement is decided by the tribal council of that settlement in consultation with the Mûppan and the tribal council of the Todikki Kurumba settlement who are the chief ritual functionaries in matters regarding Cîru in any Kurumba/Muduga settlement of Atțappâdi. It is the prerogative of the chief functionaries of the Todikki hamlet to decide the date of the Cîru after ensuring that the customary offerings to Karudaivam (the Kurumba deity) have been made and the necessary nominal daksina of either $1 \frac{1}{2}$ or $5 \frac{1}{2}$ rupees has been paid. It is particularly important that the Cîru is to be conducted in the months of April-May on a date before the onset of the Monsoon and after the sowing activities in all settlements have been finished.
It is imperative that all the Kurumba settlements should be invited to take part in it for which messengers are sent after fixing the date of the Cîru. Those Muduga settlements where Kurumbas have kin-relatives (because in recent times both the tribes have started intermarrying) and the nearby Irula settlements are also invited. The heavy expenditure of the ceremony is met from the mandatory contributions collected from every household of the settlement. A very important preliminary rite of the Cîru is the Kallukku Rāyi Âttu, performed a week before the commencement of the Cîru, in which the Mûppans and the Mannûkkârans of the 16 Kurumba settlements, along with all the other functionaries and the elders of the host settlement, take part. They pound Ragi on a big grinding stone to prepare a pastry so that this may be offered to Karudaivam of the settlement at the house of the Mannûkkâran. This offering to Karudaivam is known as Mâth Vekkal. On the seventh day after this rite the Cîru should invariably begin.

A specially decorated funeral car called Gudikkettu is constructed for the Cîru by the special functionaries of the Todikki settlement under the leadership of its Mûppan. The wooden poles for the construction of the Gudikkettu are collected from the nearby forest; custom insists that the first piece of which should be cut by the Mannûkkkâran of the settlement. The Gudikkețu resembles a pyramid; the pyramid top will be adorned with a colorful umbrella. There will be a special chamber at the bottom, called Gubbe, in which the relics of the dead are kept.

In an ongoing $C \hat{\imath} r u$, the clavicle of all the persons who had died since the last Cîru ceremony have to be collected from their graves for being deposited in the ossuary. Customarily, the clavicle of the person who had died first after the last Cîru is collected first. The clavicles of the deceased women who had been married into other settlements and who had been buried there are collected next. The bones of the deceased persons of the settlement where Cîru is organized is collected only on the first day of the ceremony. If a clavicle of a deceased person could not be traced, a ring made of silver or tharuva grass is substituted in its place. The Mudugas call the clavicle gathered from the grave Ponnellu and the rite of the recovery of these bones out of the graves is known among them as Nikaleduppu. The bones collected are washed, smeared with 
turmeric paste, covered in a new cloth and are ceremonially brought to the hamlet and put inside the Gubbe.

The placing of the sacred relics of the dead follows group wailing by the kins-women of the deceased persons. Wailing continues intermittently and as a ritualistic expression of grief. Among tribes in general, wailing is more ritualistic than emotional. Durkheim (1947) gives the exact nature of wailing thus: "one weeps, not simply because he is sad, but because he is forced to weep. It is a ritual attitude which he is forced to adopt out of respect for custom, but which is in a measure, independent of his affective state". The role of women in a Cirru is confined exclusively to their participation in the ritual dance and ritualistic wailing. Among the tribes of Kerala, rituals associated with death and funeral are a male domain where women are denied any subjective role whereas their counterparts in Africa or Australia have an equal status in funeral rites (Goody 1962).

Music and dance are essential for Cîru and are followed intermittently for three days except on occasions when some special rites take place. Music and dance is meant to entertain the spirits. To add colour to the performance and to entertain the viewers two actors play buffoonery along with the dancers, imitating monkey-gestures. There are contrasting views on the role of funeral dance in a tribal society. Block (1971: 159), in his study of the Merina of Madagascar, observed that during famadihana handling the corpse and dancing around it is a symbol and source of fertility. But the case of the Atțappādi tribes is quite different because they are scared by the very presence of the corpse and as strict followers of tradition, fear to touch it for any contact with is believed to bring infertility. Their practice conforms to the view of Campbell (1895) who has argued that music, dance and songs are used as a medium to scare away the spirits of the dead.

A very significant rite associated with the Cîru is a function held on the second day in which an amount called Pariyapanam is collected from the kinsmen of the dead persons. Since in the tribal tradition marriage is the purchase of the wife by the husband by paying bride-price to the father-in-law, and as the Atțappâdi tribes insist that if the bride-price had fallen into arrear, it should be cleared even after the death of a husband, the ceremony acquires a special relevance. While all the functionaries, including the Mûppan of the settlement and the other headmen, sit together, kinsmen of the dead married males approach them to clear off the marital liabilities and thus close the accounts of the dead in this world. If any deceased male had failed to clear the full payment of the bride-price, his kin-relatives should pay it off to his wife's father or to any of her kinsmen if father is not alive. It is customary to pay a nominal amount as Pariyapanam even if it had already been completely paid off. The longer the interval between two Cîrus, the longer will be the duration of the ceremony of Pariyapanam collection since it involves larger number of deaths and larger number of individual dealings. The rite is of crucial importance in that it reaffirms the tribal tradition of treating women as male property and yields considerable space for priestly exploitation and domination.

The chief function of the Cîru is the ritual sacrifice performed on the third day of the event. Seven male goats, bathed in the river, are made to circle the Gudikkettu before being sacrificed. It is imperative that two of the seven goats should be brought by the two senior-most sons-in-law of the hamlet known as talai-mäppila and cinnamâppila who are non-kin and belong to other Kurumba hamlets. Before being sacrificed, the goats are taken for a procession on shoulders by lifting them up and bringing down repeatedly amidst boisterous howls by people who accompany them. They are then led to circle the Gudikkettu three times. The goats are sacrificed one by one by the talaimâppila by hitting on their heads with the back of an axe. After being sacrificed the goats are drawn into the $G u b b \bar{e}$ and are later removed for being cooked. A feast with the meat of the goats sacrificed is served to all the people gathered there and is a sacred and ceremonial part of the entire ritual. It is interesting to note that right from the day of the Kallukku Rāyi Âttu, the entire inhabitants of the hamlet observe ritual pollution with a stress on vegetarianism, and the blood sacrifice signifies the cessation of this pollution. Cantlie (1981: 4244) observes that restrictions on diet are socially significant as an assertion of spiritual status; limiting the consumption of impure types of food is a means to acquire a higher rank within the tribal/caste hierarchy. Srinivas (1963) has argued that vegetarianism is one of the means by which a lower caste seek to rise to a higher position in 
ritual hierarchy through Sanskritization i.e., by transforming its ritual and pantheon by imitating the customs, rites and beliefs of the Brahmins and by adopting the Brahmanic way of life. Although the Kurumbas are very primitive, the process of sanskritization has long been under way is indicated by their worship of Siva and their participation in the grand Sivaratri festival, along with the other two tribes, once in a year, at the Malleswaran Siva temple of Atțappâdi.

The $C \hat{\imath} r u$ is concluded on the fourth day with the dismantling of the Gudikkettu and the depositing of the relics of the dead at the sacred spot where the remains of the ancestors are kept. This place is situated in the jungle away from the settlement known as Nikâlumalai (shadowland). The bones or rings are kept either in the hollow of a tree or a specially made stone structure which is known as Mâlikai or Matinați. A portion of the cooked meat of the sacrificed goats is taken along with the bone-relics and is offered to the ancestors at the Mâlikai. The Mannûkkâran has to undergo a process of pollution-removing ritual ablution and to throw away the dress that he had been wearing since the beginning of the Cîru.

\section{CONCLUSION}

Funeral rites play contradictary roles in a tribal social system as instruments of both social cohesion and economic ruin. Though funeral rituals are overtly organized in honour of the dead, practically they benefit the living. David Mandelbaum (1958: 5) opined that "rites performed for the dead generally have important effects for the living. A funeral ceremony is personal in its focus and is societal in its consequences". Firth (1951: 63) also observed that funeral rite is a social rite par excellence: "Its ostensible object is the dead person, but it benefits not to the dead, but the living". Cîru is a ritualistic gathering that reaffirms kinship ties and resolves clan-kin disputes. While family gatherings and collective enjoyments help in wielding tribal unity, a sitting of the tribal elders that accompany the main ritual help promote community interests by settling disputes among clansmen. In that sense they act as legal and juridical institutions. However, extensive postburial funeral ceremonies like Cîru are a great drain on tribal resources and a threat to the tribal economy. They exhaust tribal resources and perpetuate their economic deprivation by draining the social surplus that they would otherwise have been able to utilize for their material advancement.

The ideological foundation of the institution of Cîru is facing a serious crisis these days. The entire tribal life is presently undergoing a steady and radical process of acculturation. Tribal values are slowly being replaced by dominant Brahmanic Hindu norms. The internalization of Brahmanic cultural traits is evidently manifest in the realm of tribal religion. Tribal religion, which in its basics was animism incorporating ancestorworship, is slowly giving way to faith in Hindu gods and temple-oriented mode of devotion. In the present circumstances where ancestors themselves are accorded only a secondary position in the tribal religious pantheon, ceremonies relating to ancestor-worship like $C \hat{r} r u$ cannot be continued for long with the same intensity and devotion.

\section{REFERENCES}

Block M 1971. Placing the Dead. London: Seminar Press.

Campbell JM 1895. Notes on the Spirit Basis of belief and Custom. The Indian Antiquary, XXIV: 153169.

Cantlie Audrey 1981. Moral Significance of Food among the Assamese Hindus. In: Adrian C Mayer (Ed.): Culture and Morality. Delhi: Oxford University Press, pp. 42-62.

Durkheim Emile 1947. The Elementary Forms of the Religious Life. London: George Allen \& Unwin.

Firth Raymond 1951. Elements of Social Organization. London: Walter \& Co.

Gennep Arnold Van 1960. The Rites of Passage. Translated by Monica B. Vizedom and Gabrielle L. Loiffer. Chicago: University of Chicago Press.

Goody J 1962. Death, Property and the Ancestors: A Study of the Mortuary Customs of the Loddagaa of West Africa. London: Tavistock Publications.

Hartland Sydney E 1964. Introduction to Death and Disposal of the Dead. In: James Hastings (Ed): Encyclopedia of Religion and Ethics.. Edinburgh: T\&T Clark, Vol. I: 416-482.

Hertz Robert A 1960. Contribution to the study of the Collective Representation of Death. In: Rodney Needham and Clodia Needham (Eds.): Death and Right Hand. London: Cohen \& West, pp..27-113.

Huntington R, Metcalf P 1979. Celebrations of Death: The Anthropology of Mortuary Ritual. Cambridge: Cambridge University Press.

James EO 1957. Pre-historic Religion: A Study in Prehistoric Archaeology. London: Thames \& Hudson.

Luiz AAD 1962. Tribes of Kerala. New Delhi: The Bharatiya Adima Jati Sevak Sangh.

Mandelbaum, David G 1958. Social Uses of Funeral Rites. Eastern Anthropologist, 1: 5-24. 
Mathur PRG 1977. Tribal Situation in Kerala. Trivandrum: Kerala Historical Society.

Meighan Clement W 1951-52. Mortuary Customs in Southern India. Eastern Anthropologist, 5(4): 143161.

Miles D 1965. Socio-economic Aspects of Secondary Burial. Oceania 35: 161-74.

Poyil Manjula 2006. Death, Funeral and the Ancestors: Cult of the Dead and the Malabar Tribes. PhD Thesis (Unpublished), University of Calicut.

Rivers WHR 1986. The Todas, Vol. I. Jaipur: Rawat Publications.

Seligman Z Brenda 1964. Notes and Queries on Anthropology. London: Routledge and Kegan Paul Ltd.

Spencer Herbert 1896. The Principles of Sociology. 3 Vols. New York: Appleton.

Sreekumar KS 1992. Artistic Tradition of Kerala: A Study Based on the Art Forms of Irulas, Mudugas and Kurumbas (Malayalam). PhD Thesis (Unpublished), University of Calicut.
Srinivas MN 1963. Sanskritization and Westernization. In: A Aiyappan, LK Balaratnam (Eds.): Society in India. Madras: Social Science Association, pp.73234.

Sutton Deborah 2002. Horrid Sights and Customary Rights: The Toda Funeral on the Colonial Nilgiris. The Indian Economic and Social History Review, 39(1): 45-70.

Taylor Edward B 1871. Primitive Culture. 2 Vols. London: John Murray.

Tharakan George C 2003. The Mixed Economy of the South Indian Kurumbas. Ethnology, XLII: 4: 323 334.

Thurston Edgar 1909. Castes and Tribes of Southern India, Vol. V, Madras: Madras Government Press.

Turner V 1967. The Forest Symbols. Ithaca: Cornell University Press.

Walker Antony R 1986. The Toda of South India: A New Look. Delhi: Hindustan Publishing Corporation. 